\title{
STATUS OF LYCAENID BUTTERFLIES IN SOME SELECTED FORESTS OF BANGLADESH
}

\author{
Akand, S., M. A. Bashar and H. R. Khan \\ Environmental Biology and Biodiversity Laboratory (EBBL), Department of Zoology, University of \\ Dhaka, Dhaka-1000, Bangladesh
}

\begin{abstract}
A field investigation was carried out from January 2015 to December 2017 to study the status of some lycaenid butterflies in some selected forest areas of Bangladesh. A total of 6,724 lycaenids was recorded from Butterfly Research Park at Bhawal National Park, Gazipur; Madhupur National Park, Tangail; Satchori National Park and Rema-Kalenga Wildlife Sanctuary of Habigonj. The dominant species was Arhopala pseudocentaurus with $21.85 \%$ relative frequency and the least abundant species was Rathinda amor with $0.75 \%$ relative frequency. Butterfly Research Park showed the maximum number of butterfly individuals with a covariance of $40 \%$ followed by Madhupur National Park (37\%), Rema-Kalenga Wildlife Sanctuary (13\%), and Satchori National Park (10\%). A significant difference $(\mathrm{F}=3.52, \mathrm{p}$-value $=0.02)$ has been assessed using 'One-way ANOVA' test. The difference in the availability of butterflies in different habitats indicated the differences in plant diversity among the forests. Lycaenid butterflies displayed highest abundance (13.19\%) in December and lowest $(5.38 \%)$ in October. There was no significant difference $(\mathrm{F}=0.72, \mathrm{p}$-value $=0.71)$ among different months throughout the study period in overall species abundance though highest number was recorded in December. The abiotic factors (viz. temperature and relative humidity etc.) influence the presence of butterflies. Lycaenid butterflies demonstrated the highest abundance $(887)$ in $26.9^{\circ} \mathrm{C}$ along with $64 \%$ relative humidity whereas the least abundance $(362)$ has been recorded at $31.7^{\circ} \mathrm{C}$ with $77 \%$ relative humidity. The significant negative correlation was found in between lycaenid abundance and temperature $(r=-0.45, p-$ value $=0.14)$, and between lycaenid abundance and relative humidity $(\mathrm{r}=-0.19$, $\mathrm{p}$-value $=0.54)$. The butterfly population increased with decreasing average temperature and relative humidity during the study period. This investigation reveals the differences in the availability of lycaenid butterflies in relation to the differences in plant population and also the effect of abiotic factors in the forest areas.
\end{abstract}

Key words: Abundance; Population dynamics; Lycaenid butterflies; Abiotic factors.

\section{INTRODUCTION}

Butterflies are distinct and easily noticeable. They are very often good entrants for studying population (Pollard 1990). Butterfly species prefer very selective habitats with rich species assemblage (Padhye et al. 2006). Butterfly population is fluctuated monthly. They are common for only a few months and rare or absent in other months of the year (Kunte 2000). The seasonal abundance might be controlled by the complex interactions with various biotic and abiotic factors (Cushman and Murphy 1993). The composition of butterfly community varies highly among seasons than among habitats (Akand et al. 2016). Plant phenology and climate are the key factors that affect butterfly population (Murphy et al. 1990, Spitzer et al. 1993, Barlow et al. 2007). Changes in abundance of various species are routine phenomena and normally unremarkable (Dunn 2007). The most natural way to define abundance is population density, i.e. the number of individuals per unit of area (Komonen et al. 2011). The abundance of adult butterfly species is closely associated with the abundance of flowers, the key nectar source for butterflies (Faber et al. 1996, Steffan-Dewenter and Tscharntke 1997, Bergman et al. 2008). The abundance of lycaenid species varies according to its own ecological requirements (Akand $e t$ al. 2016). Lycaenid butterflies are rather small in size, brilliantly coloured showing marked sexual dimorphism that always occurs as a difference on the upper wing surface. But ventrally both are usually similar (Roberts 2001). These butterflies belong to family Lycaenidae under the order Lepidoptera 
comprising about 6,000 species in worldwide distribution and have the greatest diversity in the tropics (Ackery and Vane-Wright 1984).

Factors other than host plant specialization and host plant availability have marked correspondent over interspecific differences in the abundance of lycaenid butterflies (Hughes 2000, Akand et al. 2016). Host plant availability does not explain differences in the relative abundances of lycaenid species. Some lycaenids are affected by the availability of their resources. The abundance of a lycaenid species is positively correlated with its local distribution (Hughes 2000). They prefer weather variables for their species richness (Akand et al. 2016), abundance and distribution (Sei-Woong 2003, Kivinen et al. 2007). Butterflies are highly sensitive to changes in microclimatic and habitat condition (Kocher and Williams 2000, Parmesan 2003). Bashar (2010) claimed that butterflies have got serious sensitiveness to determine the phenological changes in the plants. Then the population sustenance of butterflies gives them the "status of indicators" for forecasting impact of climatic changes and for the sustenance of biodiversity in an ecosystem. The seasonal availability of host plants may be an important feature facilitating the use of lycaenids as indicators of habitat quality (Robbins and Aiello 1982). By using butterflies as indicators, increase of species richness and species assemblage have been augmented to $47 \%$ in a wild state. This wild state has been used as the healthy habitat for all kinds of animals (Bashar 2010). The present study has been envisaged with an outlook to examine the abundance and dynamics of lycaenid population through temporal and spatial patterns.

\section{MATERIAL AND METHODS}

The present research work was carried out from January 2015 to December 2017. The findings were accumulated based on the observation of four different forest areas, viz. Butterfly Research Park (BRP) a semi natural ecosystem at the Bhawal National Park (BNP), Gazipur, and three natural forests: Madhupur National Park (MNP), Tangail; Satchori National Park (ScNP) and Rema-Kalenga Wildlife Sanctuary (RKS) of Habigonj (Fig. 1). The BRP is an area of three acres $\left(100 \times 42 \mathrm{~m}^{2}\right)$ land in the premises of Bhawal National Park. The area is situated at $90^{\circ} 24^{\prime} 06^{\prime \prime} \mathrm{E}$ longitude and $24^{\circ} 05^{\prime} 06^{\prime \prime} \mathrm{N}$ latitude. This area is designed with four area-components as hedge-boundary (10\%), canopy-tree area (30\%), jungle-bush hedges $(30 \%)$ and multimorphic bed-areas (30\% of total experimental area). The MNP is deciduous with a slight mixture of evergreen forest, interspersed with hillocks. It lies between $24^{\circ} 45^{\prime} \mathrm{N}$ and $90^{\circ} 5^{\prime} \mathrm{E}$, and encompasses an area of 8,430 ha. The ScNP occupies at $91^{\circ} 27^{\prime} 2.52^{\prime \prime}$ E longitude and $24^{\circ} 7^{\prime} 12^{\prime \prime} \mathrm{N}$ latitude, and built on 243 hectors of land. The Park originally supported vegetation covering mixed tropical evergreen forests. The RKS is situated in between $24^{\circ} 10^{\prime} 53^{\prime \prime} \mathrm{N}$ and $91^{\circ} 38^{\prime} 13^{\prime \prime} \mathrm{E}$. It is a tropical forest with natural and cultivated plantations under Kalenga beat.

The population abundance of lycaenids was investigated by using transect counting, Latin squares design (LSD) of sampling, and 4-assessors 'butterfly-plant assessment model'. Transect counting was made following Pollard (1977), Pollard and Yates (1993) and Natuhara et al. (1996). The butterfly populations were estimated following Bashar (2017) with a slight modification of experimental transect as $100 \times 100 \mathrm{~m}^{2}$. LSD was adopted following Rao and Richard (2006) with modifications as suggested by Bashar (2017). The 'butterfly-plant assessment model' was used which dealt with the practice to record butterflies. Four assessors were assigned in the field $\left(100 \mathrm{~m}^{2}\right.$ area); this procedure was followed according to Bashar (2017).

The presence of lycaenid butterflies were assessed following Akand et al. (2016). The butterfly activities in the study sites were recorded through a "constant walk" for 10-15 minutes along the experimental sites. Observations were made twice in a month during the time between 9.30 a.m. and 4.30 p.m., and recorded the individual numbers of lycaenid species. The pre mating, mating, egg laying, foraging, basking, resting, puddling and flying activities of lycaenids were counted to assess their 
abundance. Only ocular observations were made for counting. Visual census of butterfly was used to show species richness.

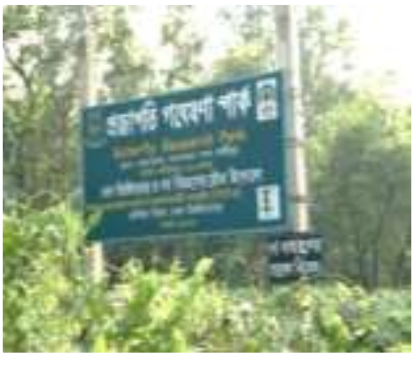

a

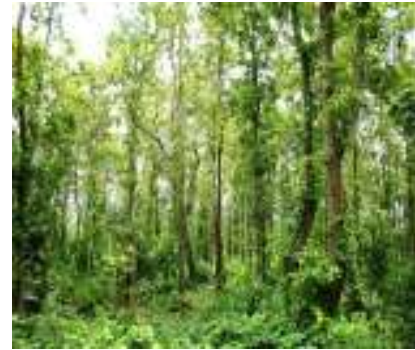

b

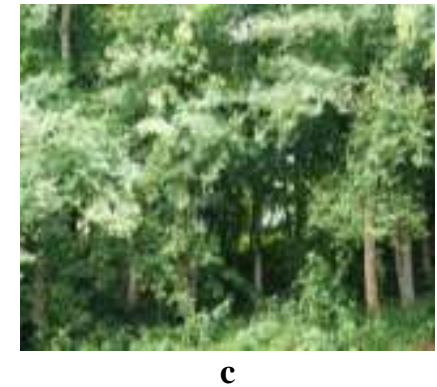

c

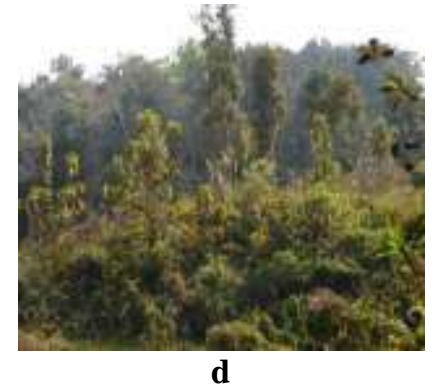

d

Fig 1. Pictorial view of different experimental forest areas: a. Butterfly Research Park; b. Madhupur National Park; c. Satchori National Park; and d. Rema-Kalenga Wildlife Sanctuary.

Butterfly species were identified directly in the field or in difficult cases following photography. The daily readings of abiotic factors (temperature and relative humidity) on each sampling day were recorded and used for the calculation of monthly mean temperature and relative humidity. One-way ANOVA was used to calculate the differences and Pearson's rank correlation is used to assess the relationships of abundance within experimental sites and months during the study period. The Spearman rank correlation is used to assess the relationship between butterfly abundance and abiotic factors.

\section{RESULTS AND DISCUSSION}

A total of 6,724 individuals representing 25 lycaenid species was counted in four experimental forests. Among them, maximum $(2,721)$ lycaenids were recorded from the BRP and minimum (673) from the ScNP; the rest 2,482 and 848 butterflies were counted from the MNP and the RKS, respectively. The relative abundance of a species was compared to other species in the study sites. In the analysis of relative abundance (Fig. 2), it was found that the dominant species was Arhopala pseudocentaurus with relative frequency of $21.85 \%$ (1467) and the least abundance was observed in case of Rathinda amor with relative frequency of $0.75 \%$ (50). Moderate population was recorded in Castalius rosimon (6.5\%), Rapala manea (5.75\%), Remelana jangala (4.80\%), Chilades lajus (4.20\%), Euchrysops cnejus (4.15\%), Pseudozizeeria maha (3.95\%) and Catochrysops strabo (3.55\%) (Fig. 2).

Suitable abiotic and biotic factors such as climate, temperature and wind exposure, availability of host and larval plants (Barlow et al. 2007), food and vegetation (Ravindra et al. 1996, Khan et al. 2004, Jain and Jain 2012, Kharat et al. 2012, Kumaraswamy and Kunte 2013), topographic features (Amala et al. 2011), habitat quality (Barlow et al. 2007) are some of the most important parameters to determine butterfly population in an ecosystem. It is very important to keep assessing the change in their abundance and distribution to evaluate biodiversity trends in a large scale.

It was detected that 53 plant species representing 25 families were related to lycaenid activities in experimental areas. Among them the families Asteraceae and Poaceae comprise nine and five plant species, respectively. The families Amaranthaceae, Lamiaceae, Fabaceae, Rubiaceae and Rutaceae contain three plant species each. The rest of the families have single or two plant species. Among the plant species 30 species are herbs, 15 shrubs and rest others are trees or palms. Butterfly diversity is largely dependent on the rich floral diversity. And plants have importance in increasing the butterfly population and their abundance in a specific area. In determining the pattern of butterfly community, relative abundance of butterfly and plant resources was an important aspect that characterizes butterfly community (Yamamoto et al. 2007). Types of vegetation may reflect difference in the composition of butterfly populations among habitats at generic and family levels (Beccaloni 1997). The lycaenid 
butterflies are found more abundant in collecting nectar on flowering plants. They spent less time on other plants (non-flowering stage). Nectar and shelter plants are more available than host plants for lycaenid butterflies in the experimental sites. Lycaenid butterfly was more synchronized with herbs and shrubs than trees as well as with ground level vegetation (Akand 2012). Incidence of natural enemies is also important. Butterflies are food to birds and other predators, and are hosts of parasitoids. These animals have affected the butterfly population.

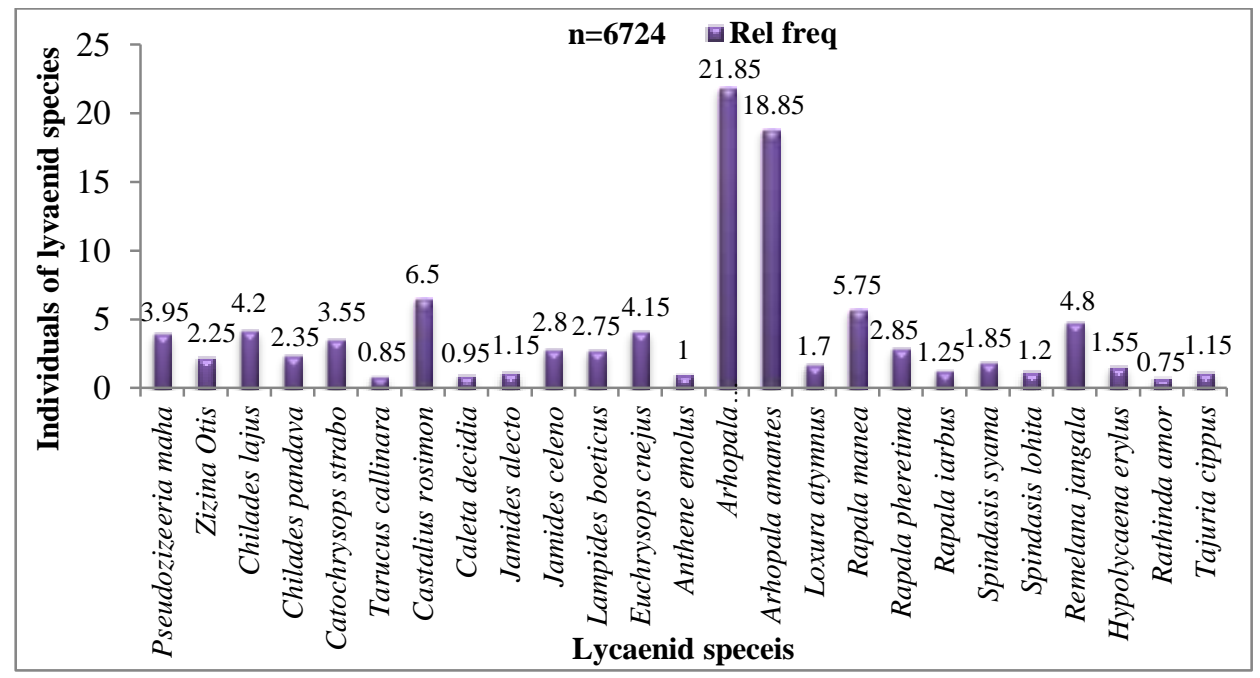

Fig. 2. Relative abundance (\%) of lycaenid species examined in different forest areas.

The relative abundance of insects varied significantly among the habitats (Akand 2012). The present investigation reveals similar pattern during the study periods. The population fluctuation might depend on biotic factors (viz. plant availability and flowering periods of plants) (Akand et al. 2016). The recorded data on butterfly abundance showed a similar array of seasonal fluctuation in all the four experimental sites (Fig. 3).

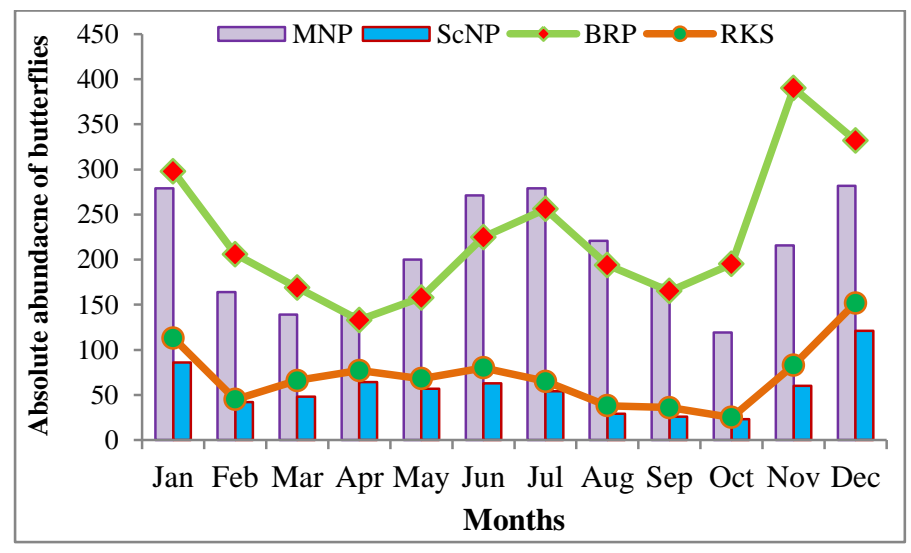

Fig. 3. Pattern of fluctuation in butterfly availability on different experimental sites during study period (2015-2017).

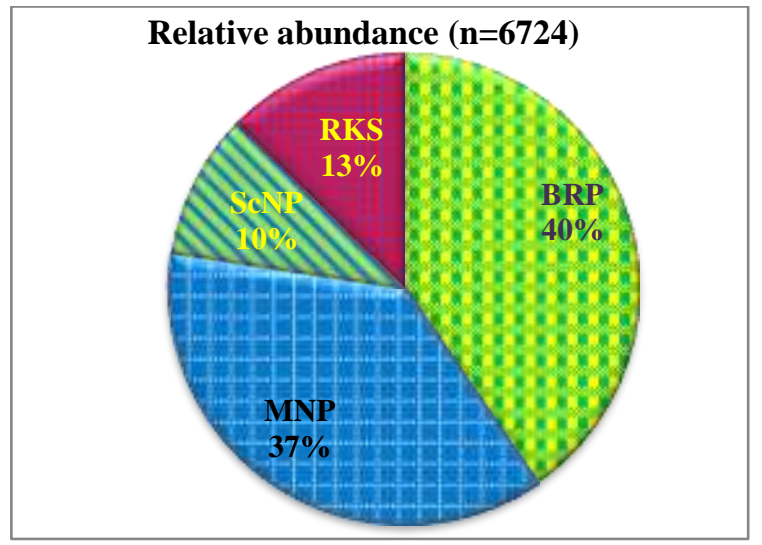

Fig. 4. Spatial pattern of lycaenid abundance in different experimental sites during study period (2015-2017).

The relative abundance of butterflies showed much temporal fluctuation during the study period in all the forests (Fig. 4). The BRP showed the maximum amount of butterfly individuals with a covariance of $40 \%$ followed by MNP (37\%), RKS (13\%) and ScNP (10\%). In a habitat comparison of lycaenid butterflies, sixteen species of 25 examined species were available in all the experimental forest sites (Table 1). Six species, viz. Tarucus callinara, Caleta decidia, Rapala iarbus, Spindasis lohita, Rathinda 
amor and Tajuria cippus were not seen in ScNP and RKS during sampling period. On the other hand, Jamides alecto was not found in BRP and MNP. Rapala pheretima and Anthene emolus were not observed in the ScNP. Lycaenids showed a mark variation in numbers among different habitats. Arhopala pseudocentaurus was the dominant species (number) in all the experimental sites. The least variation of lycaenids was marked in different forests. Hypolycaena erylus showed least number in the BRP whereas few individuals of Rathinda amor were observed in the MNP. Loxura atymnus and Anthene emolus showed least numbers in ScNP and RKS, respectively.

A significant difference $(\mathrm{F}=3.52, \mathrm{p}$-value $=0.02)$ was assessed when using 'One-way ANOVA' test. The difference in the availability of butterflies among different habitats might be indicated the differences in plant diversity among the forests. The highest numbers in the BRP indicated the rich floral diversity related to lycaenid butterflies. The least numbers of the butterfly numbers was observed in ScNP due to relatively less vegetation diversity associated with lycaenid butterflies.

Table 1. Spatial pattern of lycaenid availability in different experimental sites from 2015 to 2017.

\begin{tabular}{lccccc}
\hline Species & BRP & MNP & ScNP & RKS & Total \\
\hline Pseudozizeeria maha & 80 & 72 & 46 & 66 & 264 \\
Zizina Otis & 46 & 38 & 30 & 32 & 146 \\
Chilades lajus & 94 & 77 & 49 & 75 & 295 \\
Chilades pandava & 62 & 51 & 22 & 22 & 157 \\
Catochrysops strabo & 93 & 63 & 37 & 45 & 238 \\
Tarucus callinara & 38 & 22 & - & - & 60 \\
Castalius rosimon & 164 & 127 & 69 & 77 & 437 \\
Caleta decidia & 38 & 24 & - & - & 62 \\
Jamides alecto & - & - & 36 & 41 & 77 \\
Jamides celeno & 29 & 38 & 49 & 59 & 175 \\
Lampides boeticus & 67 & 42 & 26 & 38 & 173 \\
Euchrysops cnejus & 101 & 100 & 36 & 48 & 285 \\
Anthene emolus & 29 & 23 & - & 15 & 67 \\
Arhopala pseudocentaurus & 619 & 695 & 71 & 82 & 1467 \\
Arhopala amantes & 516 & 621 & 59 & 72 & 1268 \\
Loxura atymnus & 42 & 27 & 18 & 25 & 112 \\
Rapala manea & 178 & 122 & 33 & 42 & 375 \\
Rapala pheretima & 108 & 71 & - & 20 & 199 \\
Rapala iarbus & 61 & 36 & - & - & 97 \\
Spindasis syama & 39 & 39 & 22 & 25 & 125 \\
Spindasis lohita & 60 & 32 & - & - & 92 \\
Remelana jangala & 158 & 87 & 40 & 37 & 322 \\
Hypolycaena erylus & 25 & 22 & 30 & 27 & 104 \\
Rathinda amor & 31 & 19 & - & - & 50 \\
Tajuria cippus & 43 & 34 & - & - & 77 \\
\hline Total & 2721 & 2482 & 673 & 848 & 6724 \\
\hline
\end{tabular}

Though the overall abundance of lycaenid population varied in all the habitats, Pearson's rank correlation coefficient indicated a significant (95\% confidence level) interhabitat relationship in the species examined (Table 2).

Table 2. Correlation among the butterfly abundance in different study sites from January 2015 to December 2017.

\begin{tabular}{lcccc}
\hline Study sites & BRP & MNP & ScNP & RKS \\
\hline BRP & 1 & & & \\
MNP & 0.99 & 1 & & \\
ScNP & 0.61 & 0.59 & 1 & 1 \\
RKS & 0.59 & 0.58 & 0.96 & 1 \\
\hline
\end{tabular}


Regarding temporal abundance, lycaenid butterflies displayed highest abundance (13.19\%) in December and lowest $(5.38 \%)$ in October from three year data recording in all experimental forest sites (Fig. 5, 6). But this phenomenon was altered in the years $(2015,2016$ and 2017) among habitats. The temporal fluctuations in abundance are an important manifestation of populations' response to the environmental conditions (Arun and Vijayan 2004). Such seasonal variation in the abundance of a species is an adaptive phenomenon evolved through evolution to take maximum advantage from the ambient environmental conditions (Arun 2000).

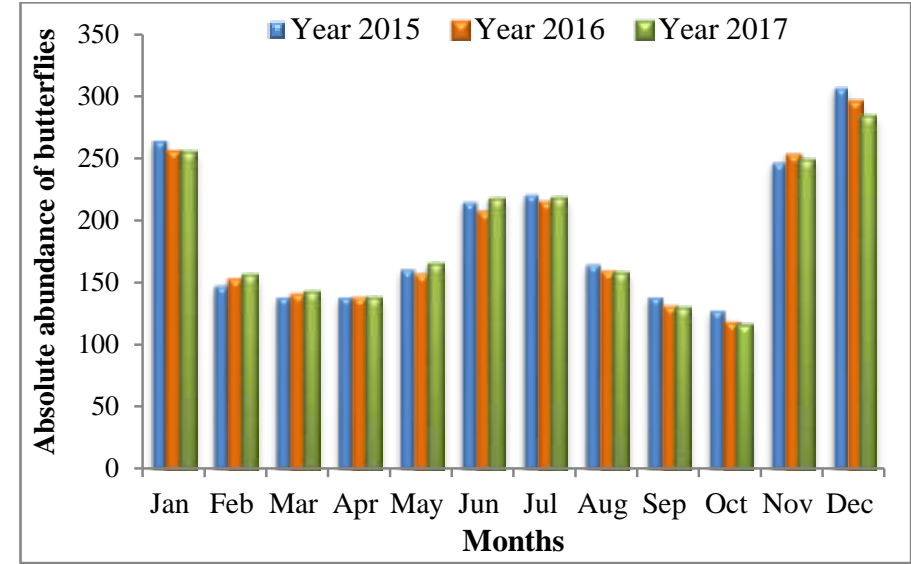

Fig. 5. Temporal fluctuation in butterfly availability in three year study period (2015-2017).

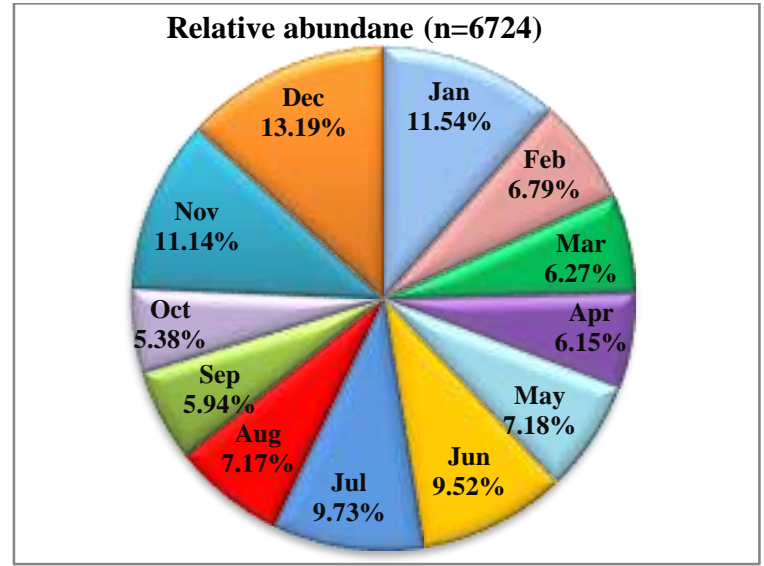

Fig. 6. Temporal pattern of lycaenid abundance during the study period (2015-2017).

In 2015, highest number (125) of butterfly was recorded in November in the BRP. On the other hand, December was the lycaenid dominating month with 96, 42 and 52 individuals recorded at MNP, ScNP and RKS, respectively. Similar pattern was found at BRP (November: 130 and 135), ScNP (December: 44 and 35) and RKS (December: 48 and 51) duing the year 2016 and 2017 except at MNP. In MNP, the highest abundance was found in July (96) in 2016 and January (92) in 2017. The temporal fluctuation is independent on habitat type (Akand 2012). This pattern was also found in the present investigation (Table 3). Butterflies are short-lived insects and most of the species are found only in few months throughout the year. The present investigation reveals similar pattern in lycaenid species. The species abundance varied in different months (Table 3). Arhopala amantes, A. pseudocentaurus and Castalius rosimon were common and found all the year round, whereas rest of the examined species were confined from three to six months in a year.

This study was also disclosed that variation among months in a particular habitat was more prominent compared to that of other habitats in a particular months. Depending on the species availability in the overall abundance data, January is the richest month having the highest number (20) of species. On the other hand, August and September were the pitiable months containing only four species (Table 3). In BRP, the maximum (19) species was visible in January and minimum (3) in September, whereas the highest (18) species appeared in November, December and January, and lowest (4) in the months of August and September at MNP. In ScNP, the maximum species (13) was found in January and minimum (4) in August, September and October while the highest species (15) was noticed in November, December and January; and lowest in August and September at RKS. Invariably in all the experimental forests lycaenid species showed their peak abundance in January and less number of species was visible in August and September.

'One-way ANOVA' was used to measure the butterfly availability in different months throughout the study period. There was no significant difference $(F=0.72, \mathrm{p}$-value $=0.71)$ though the highest 
number was recorded in December. The differences in the availability of butterflies may specify differences in plants availability and also the impacts of abiotic factor.

Table 3. Annual temporal pattern of total lycaenid availability during the study period from 2015 to 2017.

\begin{tabular}{lcccccccccccc}
\hline Species & Jan & Feb & Mar & Apr & May & Jun & Jul & Aug & Sep & Oct & Nov & Dec \\
\hline Pseudozizeeria maha & 39 & 3 & - & - & 29 & 66 & 38 & - & - & - & 37 & 52 \\
Zizina otis & 22 & - & - & - & 4 & 49 & 23 & - & - & - & 12 & 36 \\
Chilades lajus & - & 6 & 37 & 70 & 25 & - & - & 43 & 76 & 38 & - & - \\
Chilades pandava & 23 & - & - & - & - & - & - & - & - & 26 & 50 & 58 \\
Catochrysops strabo & - & 9 & 78 & 119 & 32 & - & - & - & - & - & - & - \\
Tarucus callinara & - & - & - & 3 & 8 & 30 & 19 & - & - & - & - & - \\
Castalius rosimon & 61 & 45 & 21 & 19 & 18 & 6 & 21 & 30 & 17 & 51 & 78 & 70 \\
Caleta decidia & 14 & 3 & - & - & - & - & - & - & - & - & 14 & 31 \\
Jamides alecto & 14 & - & - & - & 15 & 18 & 6 & - & - & - & 6 & 18 \\
Jamides celeno & 21 & - & - & - & 27 & 26 & 13 & - & - & 2 & 32 & 54 \\
Lampides boeticus & 4 & 41 & 82 & 46 & - & - & - & - & - & - & - & - \\
Euchrysops cnejus & - & 17 & 53 & 100 & 92 & 23 & - & - & - & - & - & - \\
Anthene emolus & 12 & 2 & - & - & - & - & - & - & - & - & 15 & 38 \\
Arhopala pseudocentaurus & 97 & 59 & 43 & 23 & 114 & 206 & 273 & 218 & 162 & 131 & 93 & 48 \\
Arhopala amantes & 77 & 59 & 33 & 24 & 104 & 173 & 241 & 191 & 144 & 103 & 86 & 33 \\
Loxura atymnus & 30 & - & - & - & - & - & - & - & - & - & 23 & 59 \\
Rapala manea & 92 & 52 & 31 & 10 & - & - & - & - & - & - & 88 & 102 \\
Rapala pheretima & 51 & 29 & 11 & - & - & - & - & - & - & - & 50 & 58 \\
Rapala iarbus & 20 & 13 & 4 & - & - & - & - & - & - & - & 29 & 31 \\
Spindasis syama & 47 & 22 & 5 & - & - & - & - & - & - & - & 26 & 25 \\
Spindasis lohita & 27 & 35 & 3 & - & - & - & - & - & - & - & 13 & 14 \\
Remelana jangala & 63 & 48 & 21 & - & - & - & - & - & - & 11 & 74 & 105 \\
Hypolycaena erylus & 49 & 13 & - & - & - & - & - & - & - & - & 13 & 29 \\
Rathinda amor & 13 & 1 & - & - & - & - & - & - & - & - & 10 & 26 \\
Tajuria cippus & - & - & - & - & 15 & 42 & 20 & - & - & - & - & - \\
\hline
\end{tabular}

During study period it was observed that the average temperature and relative humidity influenced the presence of lycaenid butterflies, which also demonstrated highest abundance (887) at $26.9^{\circ} \mathrm{C}$ and $64 \% \mathrm{RH}$ whereas, least abundance (362) recorded at $31.7^{\circ} \mathrm{C}$ and $77 \% \mathrm{RH}$ (Fig. 7). Lycaenids prefer suitable abiotic factors and their entire life directly depends on temperature, relative humidity and other abiotic factors (Akand et al. 2016).

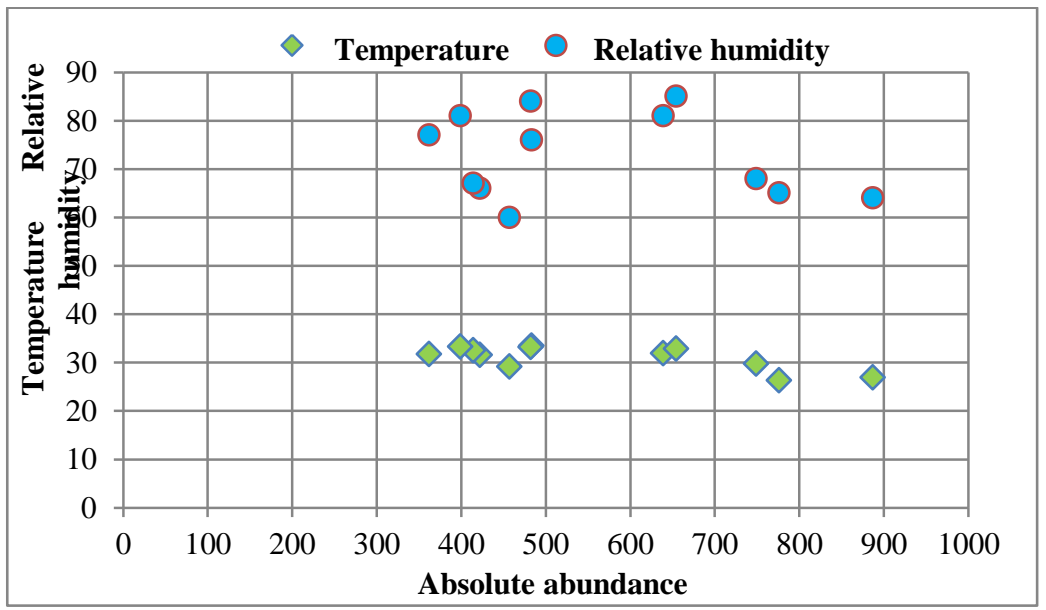

Fig. 7. The lycaenid butterflies with temperature and relative humidity during the study period. 
The relationship between butterflies and climate is complex. The correlation between abiotic factors (temperature and relative humidity) and butterfly abundance (individual of species) was calculated through the Spearman's rank correlation coefficient. The significant negative correlation found in between lycaenid abundance and temperature $(r=-0.45, \mathrm{p}$-value $=0.14)$. Similar correlation has also found in between lycaenid abundance and relative humidity $(\mathrm{r}=-0.19$, $\mathrm{p}$-value $=0.54)$. The butterfly population increased with decreasing temperature and relative humidity during the study period.

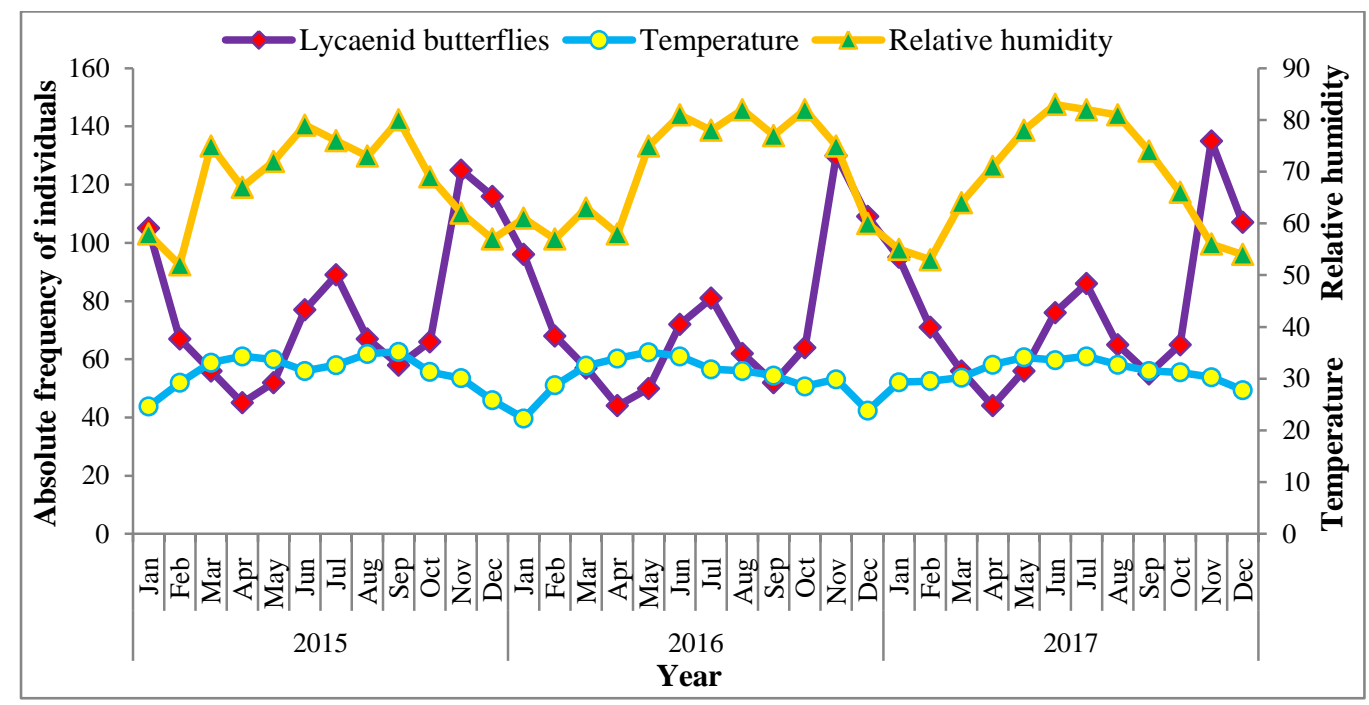

a

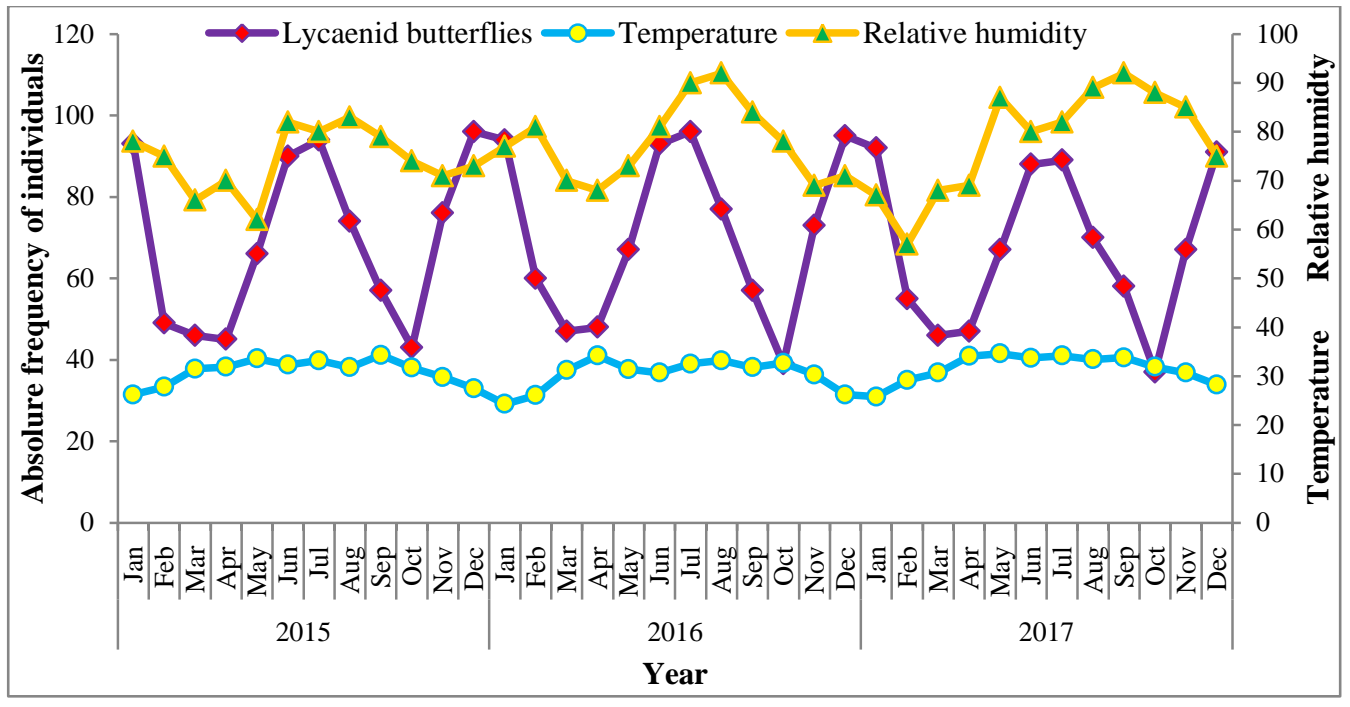

b

Fig. 8. Abundance of lycaenid butterflies with temperature and relative humidity in experimental forests: a. Butterfly Research Park; and b. Madhupur National Park.

Changes in climate have a considerable effect on different stages in the life cycle of butterflies. Daily fluctuations in temperature and relative humidity are very important to butterflies and when they are subjected to extremes heavy mortality may result (Bashar 2015). It was observed that different climatic conditions prevailed among different habitats due to their topographic and floral variation. That's why, lycaenid abundance showed marked variation in different experimental sites depending on variation in temperature and relative humidity (Fig. 8). In BRP, the highest temperature was recorded $35.2^{\circ} \mathrm{C}$ in September, 2015 and lowest temperature was $22.3^{\circ} \mathrm{C}$ in January, 2016. The highest relative 
humidity was 83\% in June, 2017 and the lowest was 52\% in February, 2015 (Fig. 8a). This experiment reveals that, the butterflies showed two peaks of abundance in a year, one being noticed in November and another during the months of June-July of the year. Of the two peaks, the November-peak always showed a greater number of butterflies than that of the June-July peak. But, the greater duration of the peak was recorded in the second peak (June-July) time. Significant negative correlation was found in between lycaenid abundance and temperature $(\mathrm{r}=-0.56, \mathrm{p}$-value $=0.003)$ while a positive correlation was found in between lycaenid abundance and relative humidity $(r=0.26, p$-value $=0.13)$. The butterfly abundance increased with decreasing temperature and increasing relative humidity. Similar pattern was experienced by Akand et al. (2015b) and Akand et al. (2016) in Butterfly Research Park.

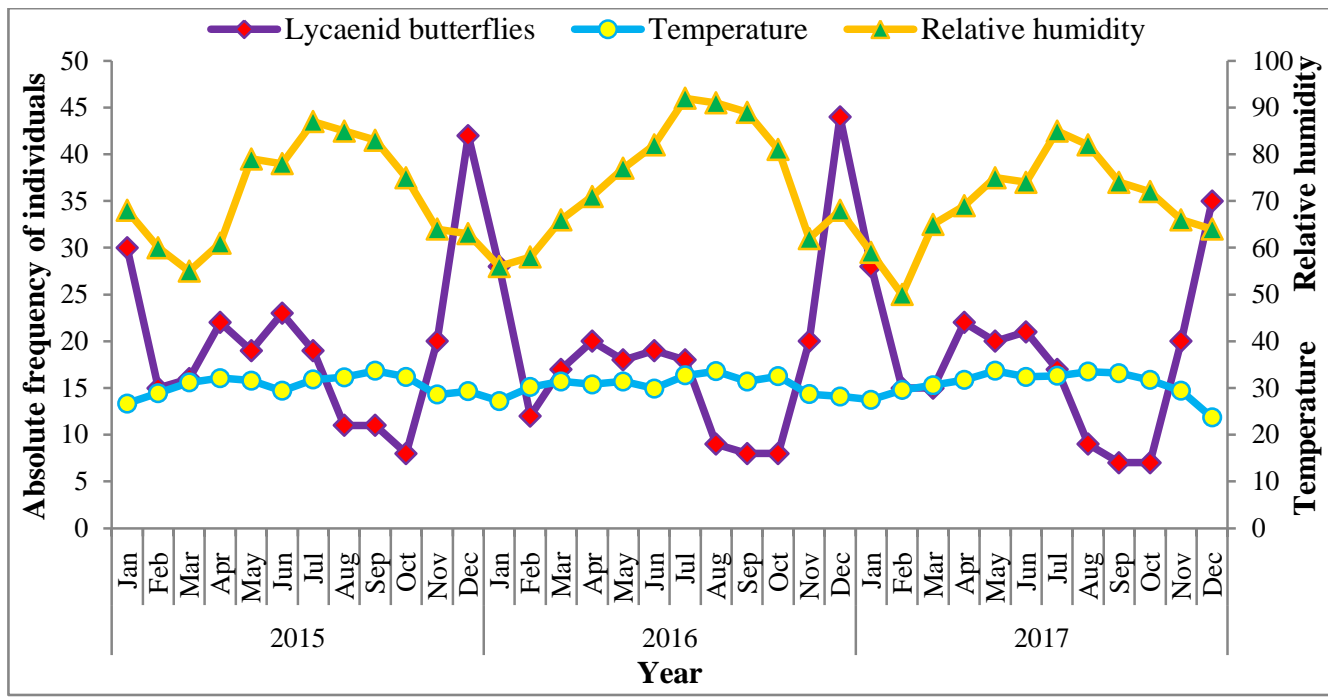

c

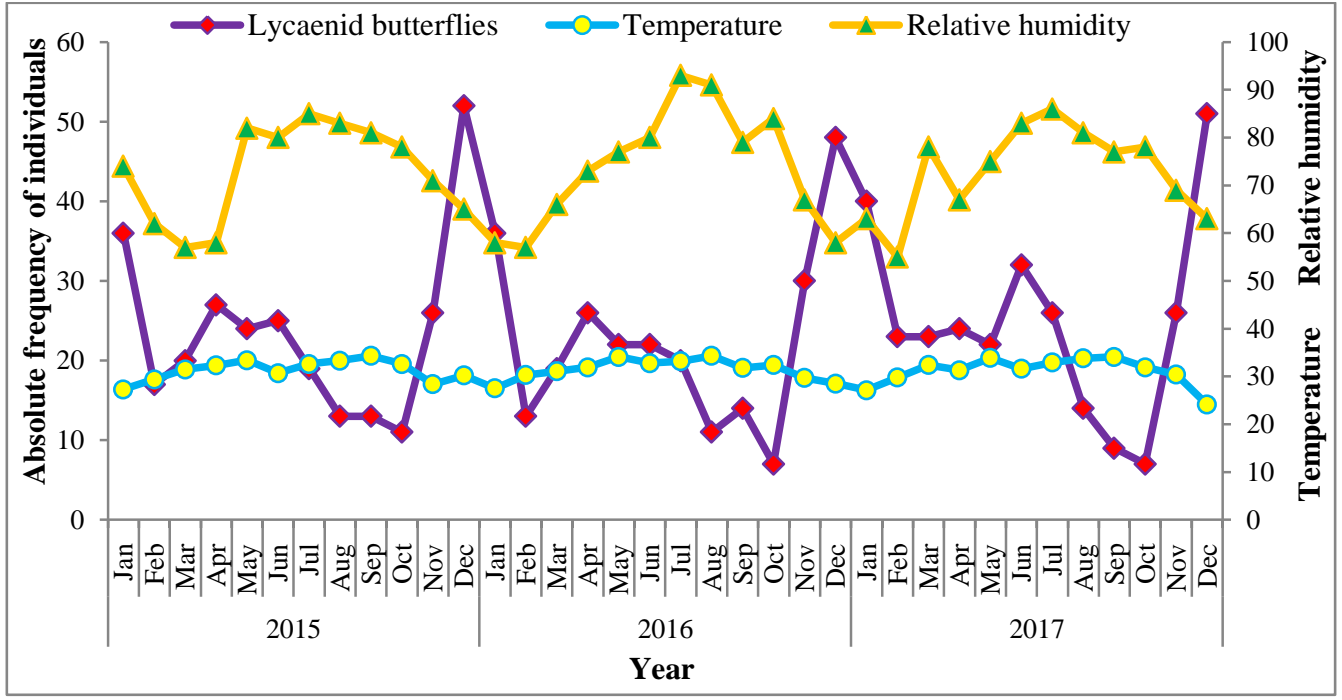

d

Fig. 8. Abundance of lycaenid butterflies with temperature and relative humidity in experimental forests: c. Satchori National Park; and d. Rema-Kalenga Wildlife Sanctuary.

In MNP, maximum temperature was recorded $34.6^{\circ} \mathrm{C}$ in May, 2017 and minimum temperature was $24.3^{\circ} \mathrm{C}$ in January, 2016. The uppermost relative humidity was $92 \%$ in September, 2017 and the lowermost was 57\% in February, 2017 (Fig. 8b). This study discloses that the butterflies displayed two peaks of abundance in a year, one in December-January and another during the months of June-July of 
the year. Of the two peaks, the December-January peak indicates the greater number of butterflies than that of the June-July peak. But, the greater duration of the peak was recorded in the second peak (JuneJuly) time. Significant negative correlation was found in between lycaenid abundance and temperature ( $\mathrm{r}$ $=-0.28$, p-value $=0.11$ ) while a positive correlation was observed in between lycaenid abundance and relative humidity $(\mathrm{r}=0.24$, $\mathrm{p}$-value $=0.16)$. According to the current examination similar pattern of correlation was found in the Butterfly Research Park (BRP).

The highest temperature $\left(33.7^{\circ} \mathrm{C}\right)$ was recorded in ScNP in the month of September, 2015. And the highest temperature records in RKS were $34.3^{\circ} \mathrm{C}$ in September, 2015 and August, 2016. The lowest temperature was $23.7^{\circ} \mathrm{C}(\mathrm{ScNP})$ and $24.1^{\circ} \mathrm{C}$ (RKS) in the month of December, 2017 (Fig. 8c, 8d). This examination reveals that the butterflies exhibit three peaks of abundance in a year. Among them the topmost one was found in December including the greater number of butterflies while two small peaks were observed during the months of April and June of the year. There was a strong and significant negative correlation found in between lycaenid abundance and temperature (ScNP: $r=-0.61$, $p$-value $<0.001$; RKS: $\mathrm{r}=-0.63$, p-value <0.001), and between lycaenid abundance and relative humidity (ScNP: $r=-0.38$, p-value $=0.02 ;$ RKS: $r=-0.41$, $\mathrm{p}$-value $=0.02$ ). The lycaenid population increased with decreasing temperature and relative humidity. But different pattern has been found in BRP and MNP by this experiment.

The present study is intended to reveal the seasonal patterns in butterfly populations, and interactions among them, the plants on which they depend, and their ecoclimate. Among the experimental forest sites, lycaenids were more abundant in Butterfly Research Park than in others. It indicates the availability of lycaenid related plants and favourable microclimatic conditions. Each habitat has a specific set of microenvironment suitable for a species (Ramesh et al. 2010). Although individually insignificant, abiotic environmental factors such as temperature and relative humidity in combination displayed a significant relation with butterfly abundance (Arun 2000, Akand 2012).

Lycaenid butterflies in all habitats displayed a highly seasonal trend as examined by Kunte (1997). The peak of species richness and abundance of butterflies was recorded in the month of November and December. Researchers reported the similar findings of lycaenid abundance (Kunte 1997, Arun 2000, 2003, Arun and Vijayan 2004, Mathew and Anto 2007, Tiple and Khurad 2009, Hussain et al. 2011, Akand 2012, Akand et al. 2015b, 2016). Temporal changes in the abundance of lycaenid butterflies can be related to the adult food sources (Hill 1992). Most of the observed species was associated with herbs and shrubs. These plants are in flowering stage in the month of November, December and January of a year. The lycaenids were synchronizing with their adult food plants. Butterflies of other families were less abundant and not herb feeder equally during this period (Kunte 1997). It is a consequence of resource-based interspecific competition for nectar-sources in adult butterflies (Akand 2012).

Butterfly species should be continuously monitored to observe any kind of change in an ecosystem. Bashar (2010) described climatic change affecting phenological changes in plants. And plant's phenological, temporal and seasonal alterations influence the life cycle of butterflies. Any abnormal change in the life cycle of butterflies affects the butterfly populations in an area. So, by observing the population fluctuation visually, 'climate change' forecasting can be estimated. Evangeline and Santhi (2016) indicated that long term assessment and monitoring of both butterfly abundance along with environmental factors are warranted to achieve better understanding and to arrive at factors responsible for abundance. Bashar (2010) has found very significant result on the question of utilizing butterflies as "biotic indicators" for monitoring climatic change impacts on biodiversity of forest ecosystems in Bangladesh. Bashar (2015) also contended that abundance of characteristic status of butterflies and their activities indicate very distinctly the healthiness of a forest. Butterflies can also indicate the dominating plant species in a forest and also can indicate whether the forest is going to be critical stage very soon or 
not. Therefore, the present study is a special effort for knowledge amalgamation about the fluctuation pattern of lycaenid population in different habitats with biotic and abiotic influence. Further researches on lycaenid diversity in forest ecosystem and the factors that affect their population dynamics will be rewarding experience.

\section{ACKNOWLEDGEMENTS}

The first author gratefully acknowledges the financial and administrative support granted by the University Grants Commission, Directorate of Secondary and Higher Education, Ministry of Education, Government of the People's Republic of Bangladesh. The EBBL, Department of Zoology, University of Dhaka acknowledges the financial support received from the Ministry of Education, GoB to conduct a grand research programme on "Butterflies of Bangladesh".

\section{REFERENCES}

Ackery, P. R. and R. I. Vane-Wright. 1984. Milkweed Butterflies: Their Cladistic and Biology. Department of Entomology, British Museum (Nat. Hist.), London, UK. 425 pp.

Akand, S. 2012. Colonization of Lycaenid butterflies on related plants and its role in the conservation of Biodiversity. M. Phil Thesis. Department of Zoology, Life and Earth Science Group, National University, Gazipur, Bangladesh. 302 pp.

Akand, S., M. A. Bashar, H. R. Khan and S. Rahman. 2016. Abundance and some behavioural aspects of lycaenid butterflies in the Butterfly Research Park at the Bhawal National Park, Gazipur. J. biodivers. conserv. bioresour. manag. 2(2): 39-46.

Akand, S., S. Rahman, K. Chowdhury, M. M. Alam, G. Moula, H. R. Khan and M. A. Bashar. $2015 b$. Behavioural activities of lycaenid butterflies and their significance with the related plants. $J$. biodivers. conserv. bioresour. manag. 1(2): 57-66.

Amala, S., M. Rajkumar and V. Anuradha. 2011. Species richness of butterflies in the selected areas of Siumalai Hills. Int. J. Pure Appl. Sci. Technol. 6(2): 89-92.

Arun, P. R. 2000. Seasonality and abundance of insects with special reference to butterflies (Lepidoptera: Rhopalocera) in a moist deciduous forest of Siruvani, Nilgiri Biosphere Reserve. South India. Ph.D. Thesis. Bharathiar University, Coimbatore, India. 236 pp.

Arun, P. R. 2003. Butterflies of Siruvani Forest of Western Ghats, with notes on their seasonality. Zoos Print J. 18(2): 1003-1006.

Arun, P. R. and V. S. Vijayan. 2004. Patterns in abundance and seasonality of insects in the Siruvani Forest of Western Ghats, Nilgiri Biosphere Reserve, Southern India. Sci. World J. 4: 381-392.

Barlow, J., W. L. Overal, I. S. Araujo, T. A. Gardner and A. P. Carlos. 2007. The value of primary, secondary and plantation forests for fruit-feeding butterflies in the Brazilian Amazon. J. Appl. Ecol. 44: 1001-1012.

Bashar, M. A. 2010. Butterflies: Best 'biotic indicators' of climatic change. The daily star (Environment). 20(17): 13.

Bashar, M. A. 2015. Butterflies of Bangladesh: A broad approach for nature lovers (EBBL Red List and butterfly acitvities). Vol. 2. BCTF publications, Dhaka-1000. 177 pp.

Bashar, M. A. 2017. Butterfly census and their eco-ethological (colonization) studies in some forests of Bangladesh. Final Project Report. Ministry of Education, People's Republic of Bangladesh. 37 pp. 
Beccaloni, G. W. 1997. Vertical stratification of the ithomiine butterfly (Nymphalidae: Ithomiinae) mimicry complexes: the relationship between adult flight height and larval host-plant height. Biol. J. Lin. Soc. 62: 313-341.

Bergman, K. O., L. Ask and P. Milberg. 2008. Importance of boreal grasslands in Sweden for butterfly diversity and effects of local and landscape habitat factors. Biodivers. Conserv. 17: 139-153.

Cushman, J. H. and D. D. Murphy. 1993. Conservation of North American lycaenids - an overview. In: T. R. New (ed.). Conservation Biology of Lycaenidae (Butterflies). IUCN, Gland, Switzerland., pp. $1-174$.

Dunn, K. L. 2007. Aspects of the biology and behaviour of Candalides consimilis goodingi (Tindale) near Melbourne, Victoria (Lycaenidae: Polyommatinae). Calodema. 10: 1-18.

Evangeline, D. and S. Santhi. 2016. Butterfly diversity at Guindy National Park in Metropolitan City of Chennai Tamil Nadu South India. J. Entomol. Zool. Stud. 5(4): 1361-1368.

Faber, R. E., H. Smith and D. W. Macdonald. 1996. The effects on butterfly abundance of the management of uncropped edges of arable fields. J. Appl. Ecol. 33: 1191-1205.

Hill, C. J. 1992. Temporal changes in abundance of two lycaenid butterflies (Lycaenidae) in relation to adult food resources. J. Lepid. Soc. 46: 174-181.

Hughes, J. B. 2000. The scale of resource specialization and the distribution and abundance of lycaenid butterflies. Oecologia. 123: 375-383.

Hussain, K. J., T. Ramesh, K. K. Satpathy and M. Selvanayagam. 2011. Seasonal dynamics of butterfly population in DAE Campus, Kalpakkam, Tamil Nadu, India. J. Threatened Taxa. 3(1): 1401-1414.

Jain, N. and A. Jain. 2012. Butterfly diversity of Hadoti Region, Rajasthan, India. Flora and Fauna. 18(2): 274-276.

Khan, M. R., A. Khurshid, B. Ikram, A. I. Malik and A. Mir. 2004. Biodiversity of butterflies from district Pooch and Sudhnoti, Azad Kashmir. Asian J. Plant Sci. 3(5): 556-560.

Kharat, A., S. Nikam and S. Gurule. 2012. Pattern of butterfly diversity from Nashik and Dhule Districts, Maharashtra. Flora and Fauna. 18(2): 243-252.

Kivinen, S., M. Luoto, M. Kuussaari and K. Saarinen. 2007. Effects of land cover and climate on species richness of butterflies in Boreal Agricultural landscapes. Agric. Econ. Environ. 122(4): 453-460.

Kocher, S. D. and E. H. Williams. 2000. The diversity and abundance of North American butterflies vary with habitat disturbance and geography. J. Biogeogr. 27: 785-794.

Komonen, A., J. Paivinen and J. S. Kotiaho. 2011. Varying definitions of abundance and incomplete assemblages challenge the generality of the interspecific abundance-distribution relationships. Ann. Zool. Fennici. 48: 161-166.

Kumaraswamy, S. and K. J. Kunte. 2013. Intergrating biodiversity and conservation with modern agricultural landscapes. Biodivers. Conserve. 22: 2735-2750.

Kunte, K. J. 1997. Seasonal patterns in butterfly abundance and species diversity in four tropical habitats in northern Western Ghats. J. Biosci. 22(5): 593-603.

Kunte, K. J. 2000. Butterflies of Peninsular India. University Press, Hyderabad, India. 254 pp. 
Mathew, G. and M. Anto. 2007. In situ conservation of butterflies through establishment of butterfly gardens: A case study at Peechi, Kerala, India. Curr. Sci. 93(3): 337-347.

Murphy, D. D., K. E. Freas and S. B. Weiss. 1990. An environment-metapopulation approach to population viability analysis for a threatened invertebrate. Conserv. Biol. 4: 41-51.

Natuhara, Y., C. Imai, M. Ishii, Y. Sakuratani and S. Tanaka. 1996. Reliability of transect count method for monitoring butterfly communities: 1. Repeated counts in an urban park. Japan. J. Environ. Entomol. Zool. 8(1): 13-22.

Padhye, A. D., N. Dahanukar, M. Paingankar, M. Deshpande and D. Deshpande. 2006. Season and landscape wise distribution of butterflies in Tamhini, Northern Western Ghats, India. Zoos' Print J. 21(3): 2175-2181.

Parmesan, C. 2003. Butterflies as bio indicators for climate change effects. In: C. L. Boggs, W. B. Watt and P. R. Ehrlich (eds.). Evolution and Ecology Taking Flight: Butterflies as Model Systems. University of Chicago Press, Chicago, USA., pp. 541-560.

Pollard, E. 1977. A method for assessing changes in the abundance of butterflies. Biol. Conserv. 12: 115-131.

Pollard, E. 1990. Monitoring butterfly numbers. In: F. B. Goldsmith (ed.). Monitoring for Ecology and Conservation. Chapman and Hall, London, UK., pp. 87-111.

Pollard, E. and T. J. Yates. 1993. Population fluctuations of the holly blue butterfly Calestrina argiolus (L.) (Lepidoptera: Lycaenidae). Entomologists Gazt. 44: 3-9.

Ramesh, T., K. J. Hussain, M. Selvanayagam, K. K. Satpathy and M. V. R. Prasad. 2010. Patterns of Diversity, Abundance and Habitat Association of Butterflies Communities in Heterogeneous Landscapes of Department of Atomic Energy (DAE) Campus at Kalpakkam, South India. Int. J. Biodivers. Conserv. 2: 75-85.

Rao, P. S. S. S. and J. Richard. 2006. Introduction of biostatistics and research methods. 4th ed. Prentice-Hall of India Private Limited, New Delhi, India. 262 pp.

Ravindra, M., S. Viswanathan and G. M. Ram. 1996. Checklist of butterfly species of Osmania University Campus, Hyderabad. Zoo's Print J. 11(10): 5.

Robbins, R. K. and A. Aiello. 1982. Food plant and oviposition records for Panamanian Lycaenidae and Riodinidae. J. Lepid. Soc. 36(2): 65-75.

Roberts, T. J. 2001. The butterflies of Pakistan. Oxford University Press. Karachi, Pakistan. 122 pp.

Sei-Woong, C. 2003. The relationship between local distribution and abundance of butterflies and weather factors. Korean J. Ecol. 26(4): 199-202.

Spitzer, K., V. Novotny, M. Tonner and J. Leps. 1993. Habitat preferences, distribution and seasonality of the butterflies (Lepidoptera: Papilionoidea) in a montane tropical rain forest, Vietnam. J. Biogeo. 20: $109-121$.

Steffan-Dewenter, I. and T. Tscharntke. 1997. Early succession of butterfly and plant communities on set-aside fields. Oecologia. 109: 294-302.

Tiple, A. D. and A. M. Khurad. 2009. Butterfly Species Diversity, Habitats and Seasonal Distribution in and around Nagpur City, Central India. World J. Zool. 4(3): 153-162. 
Yamamoto, N., J. Yokoyama and M. Kawata. 2007. Relative resource abundance explains butterfly biodiversity in island communities. Proc. Natl. Acad. Sci. USA. 104(25): 10524-10529. 